\title{
Forensic Autopsy is reviewed from the Aspects of Ethics, Medicolegal and Humanities
}

\author{
Taufik Suryadi ${ }^{1}$, Kulsum ${ }^{2}$ \\ ${ }^{I}$ Department of Forensic Medicine and Medicolegal, Faculty of Medicine, Universitas Syiah Kuala, Banda \\ Aceh, Indonesia \\ ${ }^{2}$ Department of Anesthesiology and Intensive Therapy, Faculty of Medicine, Universitas Syiah Kuala, Banda \\ Aceh, Indonesia \\ taufiksuryadi@unsyiah.ac.id, kulsumanest@unsyiah.ac.id
}

\begin{abstract}
This article is motivated by the importance of learning about forensic autopsy. A forensic autopsy is carried out on the body of someone suspected of dying due to an unnatural cause such as in cases of accidents, homicides, or suicide. Forensic autopsy includes external and internal examinations relating to respect for a deceased human body. The controversy surrounding autopsy often occurs in the community. For reasons of culture, customs and religion, there is often a refusal to do autopsy. This article discusses the importance of autopsy and aspects related to ethics, humanities and medicolegal. The medicolegal police asked to do a forensic autopsy on forensic medicine experts to find the cause of death of the victim. The purpose of this article explains about the ethical, medicolegal and humanities aspects related to forensic autopsy.
\end{abstract}

Keywords

forensic autopsy, ethics, medicolegal; humanities aspects

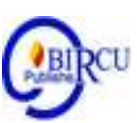

\section{Introduction}

When examining the corpse of a forensic case, the doctor is always asked by the investigator to do an autopsy on the body. Many people, especially in Aceh refuse to autopsy the body, some of the reasons given by the family are related to culture, the process of fardhu kifayah including the funeral that wants to be hastened or does not want the body to be hurt or injured. Public understanding of autopsy is certainly different from the understanding of doctors or investigators. For doctors who work in Indonesia, autopsy is a medical action at the request of the investigator, meaning that the investigator who actually needs the autopsy action is carried out in order to resolve the case that is being handled (Plattner et al., 2002; Maramis, 2016).

Autopsies or post-mortem examinations have become common practice in western medicine to verify the cause of death, and to obtain additional scientific information on certain diseases. In monotheistic religions autopsy presents some ethical questions even though the benefits generated are also recognized by people who live in this modern world. In the Islamic Republic of Pakistan where Islam is a religion followed by a majority, Pakistani society has diverse perceptions, assumptions and hypotheses on the concept of autopsy. This assumption is due to various objections raised by religion and socio-cultural context. In their context, the ritual of death is surrounded by religious and cultural beliefs and has a major influence on post mortem examinations. Objection from the religious side raises debates where opposition is against the law (Cassum, 2014; Plattner et al., 2002). 
Medical history has recorded that post-mortem surgery was first introduced from the Arab States, then progressed to Greece (Greek) and western countries and then to the rest of the world. The development from time to time through the study and study of medical experts has produced modern technology in post-mortem with a more scientific way to seek justice and truth. (Poluan, 2014). Actually how ethical, humanities and medicolegal views about forensic autopsy.

\section{Review of Literatures}

\subsection{Definition of Autopsy}

An autopsy is an examination of a corpse's body, which includes an examination of the inside and outside, with the aim of finding the disease process and / or the presence of an injury, interpreting these findings, explaining the cause of death and looking for a causal relationship between the abnormalities found with the causes death (Mansjoer, 2000; Mandong et al., 2006). Type of autopsy based on purpose: (1) clinical autopsy, (2) forensic/medicolegal autopsy, and (3) anatomic autopsy.

Clinical autopsy is conducted on the body of someone suspected of having a disease. The aim is to determine the exact cause of death, analyze the suitability between clinical diagnosis and postmortem diagnosis, pathogenesis of the disease, and so on. For this autopsy it is absolutely necessary the permission of the corpse's closest relative. Clinical autopsy should be carried out in full, but in very coercive circumstances it can also be done partial autopsy or needle necropsy on certain organs even though in both cases the conclusion is very inaccurate (Mansjoer, 2000; Amir, 2001). Forensic/ medicolegal autopsy, it is carried out on the corpse of a person suspected of dying due to an unnatural cause such as in cases of accidents, murder, or suicide (Mansjoer, 2000; Amir, 2001). Anatomic autopsy is performed on the bodies of victims who died of disease, by medical students in order to learn about human anatomy. This autopsy requires permission from the victim (before death) or his family. In an emergency, if within 2 x 24 hours a body has no family, the body can be used for anatomical autopsy (Mansjoer, 2000; Amir, 2001).

Forensic autopsy must be done as early and as accurately as possible and an objective written report based on facts in the form of visum et repertum. The purpose of a forensic autopsy examination is: (1) to help determine the identity of a corpse, (2) determine the exact cause of death, the mechanism of death, and at the time of death, (3) collect and examine evidence to determine the identity of the cause and perpetrator of the crime.

\subsection{Autopsy According to Ethical and Humanistic Aspects}

Examination of the corpse is not only related to religion and applicable law. Ethics also apply in the process of dissecting corpses. Ethics is the knowledge of morality, assessing the merits of something in terms of morals. Individuals or groups involved in the matter of autopsy corpses must fulfill the ethics outlined such as respecting, protecting the rights and glory of corpses as human beings, expediting matters of autopsy corpses, obtaining permission from inheritors to carry out autopsies, and maintaining the confidentiality of corpses. In terms of examining the body, it should be started and ended with praying for the body. Be respectful and treat the body as when it was still alive, check the conditions/conditions that are important (emergency must be checked), close the genitals of the body, respecting the family of the dead body and showing an attitude of grieving and defending condolences, not telling bad things about the dead body, not treating the body at will, still have to show empathy and sympathy. Check with affection, be gentle and carefully 
by showing a professional attitude. Guided by medical ethics, namely providing maximum benefits for the benefit of the body (the principle of beneficence), reducing the risk of the body when examined (the principle of non-maleficence), and respecting human dignity (the principle of autonomy) (Beauchamp and Childress, 2013; Jonsen et al., 2010)

\subsection{Autopsy According to Medicolegal View}

The government has decided through Indonesian Government Regulation No. 18 of 1981 concerning Clinical and Anatomical post-mortem as well as transplantation of human organs and /or tissue (Dahlan \& Trisnadi, 2019; Amir, 2001): Clinical post-mortem should only be carried out in the following circumstances:

a. With the consent of the patient and / or his immediate family after the patient dies, if the cause of death has not been determined precisely

b. Without the consent of the patient or his immediate family, if the patient is suspected of suffering from a disease that endangers others or the surrounding community

c. Without the consent of the sufferer or his closest family, if within a period of $2 \times 24$ hours none of the closest relatives who die come to the hospital. (Section 2)

Anatomical post-mortem obtained from a hospital by taking into account the requirements referred to in article 2 letters a and c (Article 5). Anatomical post-mortem can only be carried out in the anatomical ward of a medical faculty and carried out by medical faculty students and medical scholars under the direct leadership and responsibility of an expert in the analysis (Articles 6 and 7). The treatment of corpses, before, during and after anatomical post-mortem surgery is carried out with each religion and belief in God Almighty and regulated by the Minister of Health (Article 8).

While in the Criminal Procedure Code there are provisions that explain the involvement of doctors in performing forensic autopsy (Dahlan \& Trisnadi, 2019; Amir, 2001):

Article 133 of the Criminal Procedure Code:

1. In the case of an investigator in the interest of the judiciary dealing with a person who is injured, poisoned or died due to an event which constitutes a criminal offense, he is authorized to submit an expert statement request to the judicial medical expert or doctor and or other experts.

2. Requests for expert statements as referred to in paragraph 1 shall be made in writing, expressly in the letter for a post-mortem examination or post-mortem examination.

3. A corpse sent to judicial medicine or a doctor to a hospital must be treated well with respect to the corpse and labeled with the identity of the corpse carried out by giving a position cab attached to the thumb or other part of the corpse.

Article 134 of the Criminal Procedure Code:

1. In cases where it is absolutely necessary that for the purposes of proving a postmortem examination it is impossible to avoid it again, the investigator must notify the victim's family in advance.

2. In the case of the objected victim's family, the investigator is obliged to explain clearly about the purpose and objective of the surgery.

3. If within two days no response from the family or the party that needs to be notified is not found, the investigator shall immediately implement the provisions referred to in Article 133 paragraph 3 of this law.

In this legal provision it is clearly explained that the investigator determines the need for a post-mortem examination and that the investigator explains to the victim's family that the body will be examined only on the outside or through a post-mortem examination. For purposes of investigation if the victim's family objects to a post-mortem examination, the investigator may use article 122 of the Criminal Code, which is a legal sanction for those who 
prevent a post-mortem from being judged. Criminal Code Article 222: Anyone who intentionally prevents hinders or thwarts corpse examination for a court, is sentenced to a maximum of nine months imprisonment or as much as four thousand five hundred rupiah.

\subsection{Autopsy According to Sharia View}

Basically autopsy a corpse is unlawful in the view of Islamic sharia because the honor of a Muslim who has died is the same as when he was alive (Madadin \& Kharoshah, 2014). The things that underlie this law are several propositions as follows: Evidence of the Qur'an. Allah Ta'ala said in surah Al Isra verse 70: And verily we glorified the children of Adam, we transported them to land and sea, we gave them sustenance from the good and we have exaggerated them with perfect advantages over most creatures that we have created. The hadith postulate; from Aisyah Radhiyallahu "anha from the Prophet Muhammad that he said:" Verily breaking the bones of a believer when he dies is like breaking his bones while alive" Even though the original law is forbidden, it's just that, sometimes some conditions that require an autopsy so out of the original rules earlier, because at this time autopsy is often used as part of the legal process to find or corroborate evidence (Madadin \& Kharoshah, 2014; Gastrad, 1994). In this case there are 3 opinions regarding autopsy viewed from the goal itself (Madadin \& Kharoshah, 2014); Plattner, 2004).

1. An autopsy for criminal case research. Jumhur al-Mu'ashirin believes that corpse autopsies conducted for criminal case studies are permissible, this is the opinion taken from the fatma institute of Majma 'Islamic Fiqh in Makah al-Mukaramah, Hai'ah Kibar Ulama of Saudi Arabia, and Darul Fataya al-Mishriyah.

2. An autopsy for researching a disease. The correct opinion of the experts is that autopsy is allowed to study a disease, if there is a purpose and the right cause, such as someone who has a disease that can be transmitted to people around him and the outbreak of the disease has no known treatment solution. The reason for allowing both autopsies to be done is because the benefits are very large, in this case the general benefit takes precedence over the personal benefit. If there are two collisions, the lighter damage takes precedence.

3. An autopsy for scientific research to either study or teach it.

The scholars disagreed opinion in this case law, the opinion is divided into 3 (Madadin \& Kharoshah, 2014):

1. It is absolutely permissible for this purpose. This is the fatwa of Majma 'Fiqhil Islami in Makkah in its tenth daurah.

2. Absolutely prohibited means that it is not allowed.

3. It is permissible to autopsy the bodies of infidels with the aim of scientific research or study, but it is not permissible to autopsy the bodies of Muslims. This is an opinion set by Hai'ah Kibarul Ulama in Saudi Arabia.

\section{Discussion}

An autopsy is an examination of a corpse's body, which includes an examination of the inside and outside, with the aim of finding the disease process and / or the presence of an injury, interpreting these findings, explaining the cause of death and looking for a causal relationship between the abnormalities found with the causes Dead. In this case the police submitted an autopsy request which included an internal and external examination on the victim. This is in accordance with Article 133 of the Criminal Procedure Code paragraph 1 which reads "In the case of an investigator in the interest of the judiciary dealing with a 
person who is injured, poisoned or dead due to a criminal event, he is authorized to submit an expert statement to the judicial medical expert or doctor and or other experts ". After explaining to the family about the need for an internal examination or post-mortem examination on the victim's family, the victim's family agrees to carry out this action. the body could not have been avoided anymore, investigators were required to notify the victim's family first.

In terms of religion, the law of origin for post-mortem is prohibited. But even though the original law is forbidden, sometimes some conditions require for post-mortem to come out of the original rules earlier. Because at this time in the examination or post-mortem is often used as part of the legal process to find or strengthen the evidence (Madadin \& Kharoshah, 2014; Gastrad, 1994). One of the conditions permitted by post-mortem surgery is for criminal case studies. Jumhur al-Mu'ashirin believes that corpse autopsies conducted for criminal case studies are permissible, this is the opinion taken from the fatma institute of Majma 'Fiqh Islami in Makah al-Mukaramah, Hai'ah Kibar Ulama of Saudi Arabia, and Darul Fataya al-Mishriyah. In this case, the purpose of conducting a post-mortem examination on the victim is aimed at revealing the cause of death to the victim so that it is included in one of the conditions that permit an internal examination or post-mortem examination (Madadin \& Kharoshah, 2014; Gastrad, 1994).

\section{Conclusion}

Forensic / Medicolegal autopsy is carried out on the body of someone suspected of dying due to an unnatural cause such as in cases of accidents, killings, or suicide. In Islamic teachings, the law of origin of an autopsy is haram, but in some circumstances the original legal conditions may change. Legally a forensic autopsy can be carried out if there is a request from an investigator for a judicial case and regulated in the Criminal Procedure Code articles 133 and 134. Medical practices must also be carried out with due regard to the norms prevailing in society. Besides that, in the process many norms were obeyed to maintain the honor and glory of the corpse as human.

\section{References}

Al Quran, Surah Al Isra Ayat 70

Amir A. 2001. Autopsi Medikolegal. Medan: Percetakan Ramadhan.

Arifin, M. 2020. The Efforts of Islamic Criminal Law Integration into Indonesian Law Procedures. Budapest International Research and Critics Institute-Journal (BIRCIJournal) (3): 974-984.

Beauchamp, T.L., \& Childress, J.F.2013. Principles Of Biomedical Ethics (7th Ed). New York: Oxford University Press.

Cassum LA. 2014. Refusal To Autopsy : A Society Practice In Pakistan Context. Clinical Research Bioethics Journal. 5(5): 1-4.

Dahlan S, Trisnadi S. 2019. Forensic Medicine. Sultan Agung University School Of Medicine. Semarang.

Jonsen, A.R., Siegler, M., \& Winslade, W.J. 2010. Clinical Ethics A Practical Approach To Ethical Decisions In Clinical Medicine.7th Ed. The Mcgraw Hill Companies. New York.

Gatrad, AR. 1994. Muslim Customs Surrounding Death, Bereavement, Postmortem Examinations, And Organ Transpalants. BMJ; 309.6953: 521-523. 
Madadin M, Kharoshah MA. 2014. Autopsy In Islam And Current Practice In Arab Muslim Countries. Journal Of Forensic And Legal Medicine 23 (2014): 80-83.Mandong, B. M., A. N. Manasseh, And B. T. Ugwu. 2006. Medicolegal Autopsies In North Central Nigeria." East African Medical Journal. 83(11): 626-630.

Mansjoer A. 2000. Kapita Selekta Kedokteran Jakarta: Medica Aesculpalus FKUI.

Maramis. 2016. Tinjauan Yuridis Terhadap Otopsi Medikolegal Dalam Pemeriksaan Mengenai Sebab-Sebab Kematian. Jurnal Hukum Unsrat. 21(5): 85-96.

Plattner, Thomas, Eva Scheurer, And Ulrich Zollinger.2002. The Response Of Relatives To Medicolegal Investigations And Forensic Autopsy. The American Journal Of Forensic Medicine And Pathology 23(4): 345-348.

Poluan Y. 2014.Bedah Mayat Dan Akibat Hukumnya. Lex Crimen. 3(4): 124-129.

Rahman, S., Bayu, M., and Hutagalung, Z. 2020. Medical Emergency and Public Health Response in Disaster Settings: A Case Series of Pidie Jaya, Lombok and Palu Earthquakes. Budapest International Research in Exact Sciences (BirEx) Journal (2): 264-267.

Suryadi, T., and Kulsum. 2020. Identification of Ethical and Medicolegal Problems in the Care of Patients in the Intensive Care Unit. Britain International of Exact Sciences (BIoEx) Journal (2): 547-555.

Suryadi, T., and Kulsum. 2020. Student's Self-Assessment Regarding the Clinical Skills in Forensic Medicine. Budapest International Research in Exact Sciences (BirEx) Journal (2): 241-247. 